\title{
Meishu-Sama: vida e obra por um mundo livre de doença, pobreza e conflito
}

\author{
Andrea Gomes Santiago Tomita*
}

\section{Resumo}

Mokiti Okada é o nome civil do fundador da religião messiânica, conhecido religiosamente como Meishu-Sama (Senhor da Luz, em japonês 明主 「). Neste artigo, serão identificados elementos constitutivos dessa nova religião, com especial atenção ao seu propósito de salvação da humanidade: desde a ênfase na cura de doenças dos japoneses do início do século XX até sua abordagem messiânica com viés mundial calcado na missão de construção do paraíso terrestre. A história de vida de MeishuSama, o nascimento e as "metamorfoses" da religião messiânica se confundem com o próprio processo de transformação vivido pelo Japão da era feudal para a era moderna. Palavras-chave: Religião. Japão. Meishu-Sama. Kannon. Messias.

\section{Meishu-Sama: life and work for a world free of disease, poverty and conflict}

\begin{abstract}
Mokiti Okada is the civil name of the founder of the messianic religion, known religiously as Meishu-Sama 明主「(literally, Lord of Light). This article aims to identify constitutive elements of this new religion, with special attention to its purpose of salvation of humanity: from healing diseases of the Japanese population from the beginning of the XX century to the messianic worldwide perspective based on the construction of paradise on earth. Meishu-Sama's life story, the creation and "metamorphoses" of the messianic religion are blended in the process of transformation experienced by Japan from the feudal era to the modern era.
\end{abstract}

Keywords: Religion. Japan. Meishu-Sama. Kannon. Messiah.

\footnotetext{
Doutora em Ciências da Religião pela Universidade Metodista de São Paulo (2009). Coordenadora de Pesquisa na Faculdade Messiânica e docente na Universidade de São Paulo.
} 


\section{Meishu-Sama: vida y obra por un mundo libre de enfermedad, pobreza y conflito}

\section{Resumen}

Mokiti Okada es el nombre civil del fundador de la religión mesiánica, conocido religiosamente como Meishu-Sama (Señor de la Luz, en japonés 明主「). Em éste artículo serán identificados elementos que constituyen una nueva religión, con especial atención a su propósito de salvación de la humanidad: desde el énfasis en la cura de las enfermedades de los japoneses del inicio del siglo XX hasta su enfoque mesiánico mundial que se refleja em la misión de construir el paraíso terrestre. La historia de la vida de Meishu-Sama, el nacimiento y las metamorfosis de la religión mesiánica se confunden com ele propio proceso de transformación vivido por el Japón de la era feudal para la era moderna.

Palabras clave: Religión. Japón. Meishu-Sama. Kannon. Mesías.

\section{Introdução}

O propósito deste artigo é apresentar a vida e obra de Meishu-Sama ${ }^{1}$ (1882-1955), bem como, o contexto sócio-histórico em que ele fundou a religião messiânica, uma das novas religiões japonesas (NRJ) mais conhecidas fora do Japão. O ideal de Meishu-Sama, desde o início, era o de erradicar a doença, a pobreza e o conflito - as três maiores desgraças que assolam este mundo. Sua motivação para tal empreitada? A própria experiência de vida como um ser humano comum que superou diversas doenças, perdeu familiares, sofreu falência, foi assolado por dívidas, viveu o terror de duas grandes guerras, viu bombas atômicas destruírem vidas, foi alvo de injustiças, difamações e até encarcerado.

Mokiti Okada é o nome civil do fundador da religião messiânica, conhecido religiosamente como Meishu-Sama (Senhor da Luz, em japonês 明主「). Nasceu em Tóquio, Japão, no dia 23 de dezembro de 1882. Compadecido pela situação caótica da sociedade japonesa do entreguerras, dedicou-se a salvar pessoas que sofriam com as mais diversas doenças, por meio do Johrei, um ritual salvífico de canalização de energia espiritual Luz Divina -, que objetiva a eliminação de problemas físicos, emocionais e pessoais, melhor dizendo, as impurezas espirituais.

\footnotetext{
1 A denominação "Meishu-Sama" foi cunhada e anunciada pelo próprio fundador Mokiti Okada apenas em 4 de fevereiro de 1950, por ocasião da instituição da Igreja Messiânica Mundial, a partir da fusão da Igreja Kannon do Japão com a Igreja Miroku do Japão. Neste texto, optamos por designar o fundador como Meishu-Sama, mesmo em se tratando de fatos ocorridos antes de 1950 .
} 
Meishu-Sama foi um homem de compleição fraca, nascido num país longínquo e exótico, que trilhou o caminho que qualquer ser humano pode trilhar: o alcance da plenitude nesta vida, ou melhor, a percepção da unidade com Deus, por meio do nome messias.

Diríamos, diante disso, que Meishu-Sama viveu a experiência de modernização do Japão do século XX. Altamente crítico da sociedade contraditória de sua época e identificado com a salvação da humanidade, denunciou abertamente que "o mundo contemporâneo é realmente o paraíso dos ricos e o inferno dos pobres" (MEISHU-SAMA, 2017, p. 45) conforme se expressou no texto intitulado "Verdade, Bem e Belo", datado de 23 de setembro de 1953.

Acompanhando o desenvolvimento da cultura, multiplicaram-se os elementos do belo. Individualmente falando, estão em nível satisfatório; mas coletivamente, não se consegue usufruir deles. Somente uma parte da sociedade - a classe privilegiada -, desfruta de roupas bonitas, boa alimentação e belas moradias, enquanto o povo em geral mal consegue alimentar-se, não tendo condições para pensar no belo. Tais pessoas dispõem de alimento apenas para matar a fome; de casa, somente para dormir; das ruas, apenas para transitar, e de um transporte coletivo, em que mal dá para entrar, pois têm de enfrentar os empurra-empurras (talvez isso ocorra somente no Japão). Dessa forma, trata-se de uma sociedade que não consegue usufruir das belezas naturais, que são dádivas de Deus, tais como as montanhas, os rios, as plantas e as flores, nem das artes e do belo criados pelo ser humano. Assim, não obstante o grande desenvolvimento da cultura, uma vez que não é toda a humanidade que pode usufruir de suas benesses, o mundo contemporâneo é realmente o paraíso dos ricos e o inferno dos pobres. A causa é a existência de uma grande falha em algum ponto da civilização. Somente quando esse equívoco for corrigido e a felicidade puder ser desfrutada equitativamente, o mundo será, de fato, civilizado. Esta é a missão da Igreja Messiânica Mundial (MEISHU-SAMA, 2017, p. 45).

\section{Kanzeon Bosatsu, ${ }^{2}$ nome da grande piedade, é sinônimo de Messias $^{3}$}

Meishu-Sama nasceu em Tóquio, mais especificamente em Asakusa, no bairro Hashiba, no município de Taito, que é bastante reconhecido

2 Kanzeon Bosatsu: Em sânscrito, Avalokiteshvara ("Aquele que enxerga os clamores do mundo") é o bosatsu (ser iluminado, em sânscrito bodhisattva) que representa a suprema compaixão. Conhecido no Japão também apenas como Kannon. Em chinês, é chamado de Kuan Yin. Em línguas ocidentais, é conhecido como Deusa da Misericórdia.

3 FUNDAÇÃO MOKITI OKADA, 1983, v. 3, p. 223. Esse subtítulo é um poema de autoria de Meishu-Sama. 
por possuir um templo budista, o Templo Sensoji, dedicado a Bodhisattva Kannon, que representa a piedade ou compaixão. Mais tarde, a partir de sua experiência religiosa, o próprio fundador escreveria sobre a mística que envolve o seu nascimento no local mais a leste da capital de Tóquio, que significa "cidade do leste", relacionando-o à sua missão messiânica.

Ao longo de sua trajetória, evidencia-se, por sua vez, uma forte ligação com a religiosidade budista. A respeito de sua infância pobre e de sua proximidade com o universo budista, Meishu-Sama escreveu o seguinte:

Nasci em Hashiba, bairro localizado em Assakussa, Tóquio. Lembro-me vagamente de que meu pai negociava com objetos usados e de que nossa casa só tinha dois cômodos: um, com mais ou menos 4,90 m2, onde funcionava a loja, e uma sala de estar com aproximadamente $7,30 \mathrm{~m} 2$. Todas as noites, ele ia ao Parque Assakussa, distante mais ou menos 1 quilômetro, para abrir sua barraca noturna. Desde que tenho consciência, muitas vezes ouvi meu pai falar que, se não conseguisse determinada quantia naquela noite, não teríamos o que comer no dia seguinte. Então; caso não chovesse, ele carregava uma pequena carroça com alguns utensílios velhos, e minha mãe, levando-me às costas, ia empurrando-a. Vivendo numa pobreza extrema, ela ficou desnutrida e, como não tinha leite para me amamentar, ia pedir leite materno à esposa de um bonzo do Templo Renso-ji, que ficava próximo. (...) Portanto, em minha infância, e mesmo quando já tinha uma família para cuidar, durante um bom espaço de tempo provei o sabor da pobreza, podendo compreender o quanto o dinheiro é motivo para gratidão. Isso me foi de grande proveito, pois ainda hoje não consigo desperdiçar nada, nem viver no luxo, de modo que sou até grato pela adversidade daquela época (FUNDAÇÃO MOKITI OKADA, 1985, p. 77).

Reza a lenda que as origens do Templo Sensoji, situado no Parque Asakusa, remontam à descoberta da estátua de (Bodhisattva) Kannon, no rio Sumida, em 628, por dois pescadores, os irmãos Hinokuma Hamanari e Hinokuma Takenari. Desde a antiguidade, é sabido que orar diante da imagem de Kannon traz como benefício a eliminação das doenças e dos infortúnios. A título de curiosidade, o pai de Meishu-Sama vendia objetos de arte para o sustento da família em Tóquio justamente no Parque Asakusa.

Antigamente, a capital Tóquio era chamada Edo e as pessoas que nesta nasciam eram chamadas de edoko. Meishu-Sama foi um edoko, criado em Asakusa, que se tornou um centro cultural e um local sagrado para pessoas que costumavam visitar o templo Sensoji. Ser um edoko era sinônimo de ser 
uma pessoa assertiva, direta, inclinada às atividades comerciais e entusiasta da cultura popular.

Como mencionado, Meishu-Sama nasceu em 1882, isto é, no $15^{\circ}$. ano do período Meiji, que representa o início da modernização da sociedade japonesa, que passou de uma sociedade feudal isolada para uma sociedade ocidentalizada. Naqueles tempos, mudanças fundamentais ocorreram na estrutura social, educacional, política interna, economia, nas relações militares e estrangeiras. A coletânea Luz do Oriente traz informações importantes sobre o contexto histórico do Japão dessa época:

Os dirigentes do governo Meiji, desejando recuperar o atraso da modernização do Japão em relação às potências européias e aos Estados Unidos, empenharam-se ao máximo para introduzir e absorver a cultura, a ciência e a técnica ocidental. Especialmente com o objetivo de formar elementos humanos úteis à Nação, deram elevada importância ao ensino moderno e colocaram todo o empenho na difusão do órgão educativo sistemático chamado escola. (...) Em julho de 1890, realizou-se a primeira eleição para deputados, e em novembro, a primeira sessão do Congresso Nacional. No mês anterior, ou seja, em 30 de outubro de 1890, foi promulgado o decreto imperial referente ao ensino. Este decreto representava uma cautelosa medida do Imperador Meiji para que não houvesse vacilações nos métodos de ensino nacionais em conseqüência da promulgação da Constituição, da criação do Congresso Imperial, da mudança do Gabinete etc. Nele está bem esclarecida a diretriz fundamental do ensino no Japão, a qual serviu de modelo para o povo japonês até o término da Segunda Guerra Mundial. Dessa forma, entre os anos de 1877 e 1896, época em que o Japão ia se configurando como nação moderna, planejou-se a organização e aperfeiçoamento do sistema de ensino como importante política para atingir a modernização. Foram instaladas muitas escolas primárias públicas, e os - terakoya e os shijuku existentes desde a Era Edo tiveram reconhecimento oficial como escolas públicas ou particulares. Dessa forma, o aumento de escolas primárias, no início da Era Meiji, foi espantoso. Nas escolas primárias particulares, o professor usava uma peça de sua residência como sala de aula, e nela se reuniam várias turmas de alunos. Havia muitas escolas assim, do tipo - terakoya. No Pedido de Instalação de Escola Primária, registro existente ainda hoje, consta que a Escola Primária Básica Nishin, a primeira que o Fundador freqüentou, abrigava cinqüenta alunos e um professor numa área de apenas $25 \mathrm{~m}^{2}$. Através disso, podemos ter uma idéia das suas condições. Entretanto, se existiam escolas pequenas e humildes como essa, também havia escolas de bom conteúdo e instalações,

4 Considerável referência relativa à vida do Fundador Meishu-Sama e ainda à história e teologia da Igreja Messiânica Mundial, em seus primórdios. 
como a Escola Primária Assakussa, estabelecimento público para onde o Fundador se transferiu posteriormente. Em verdade, até as escolas primárias de Tóquio situadas bem perto da sede do novo governo encontravam-se nesse estado confuso (FUNDAÇÃO MOKITI OKADA, 1985, p. 95-98).

A despeito de todas as dificuldades do período inicial de implantação do sistema educacional do período Meiji, Meishu-Sama concluiu os estudos primários aos 13 anos de idade e ingressou na Escola de Belas-Artes. Embora seu interesse e ligação com as Artes tenham marcado profundamente sua vida pessoal e religiosa, nessa época Meishu-Sama viu frustradas suas expectativas ao ser obrigado a abandonar seu sonho de se tornar um artista.

\section{Meishu-Sama: retratos do Japão em modernização no início do Século XX}

Em sua juventude, Meishu-Sama teve uma saúde frágil. Devido a problemas de visão foi obrigado a deixar os estudos e, dois anos depois, foi acometido de pleurisia e posteriormente de tuberculose. Submeteu-se a tratamentos, mas foi por meio de dieta vegetariana que superou a doença. Durante sua juventude, interessou-se por filosofia ocidental, sobretudo pelas ideias de Henri Bergson e William James.

Com a morte de seu pai, Meishu-Sama, aos 23 anos de idade, recebeu como herança uma quantia que utilizou para abrir uma loja de miudezas, em 1905, a Korin-do, nome dado em homenagem ao artista Korin Ogata (16581716) - alvo de sua grande admiração. Nessa época, o Japão se encontrava em plena fase de modernização, e havia iniciado a guerra contra a Rússia.

Os negócios prosperaram e, assim, Meishu-Sama estabeleceu uma loja atacadista de adornos - a Loja Okada - em 1907, mesmo ano que se casou com Taka Aihara. Por três vezes, sua esposa deu à luz crianças que morriam logo após o nascimento. Devido ao tifo intestinal, contraído antes do terceiro parto, Taka acabou morrendo em junho de 1919. Nesse mesmo ano, Meishu-Sama sofreu um duro golpe, que o levou à falência e lhe deixou dívidas que perduraram por mais de 20 anos. Também sofreu uma grave isquemia cerebral, e, ao longo de dez anos contraiu várias enfermidades: crise de hemorroida, dor de cabeça e estômago, reumatismo, prostração nervosa, uretrite, amigdalite, catarro intestinal, problema das válvulas cardíacas, periodontite, dor de dente, entre outras. Em dezembro de 1919, aos 37 anos de idade, casou-se pela segunda vez com Yoshi Ota. 
Nessa fase de sua vida, Meishu-Sama viveu as dificuldades decorrentes da Primeira Guerra Mundial (1914-1918): falência, perdas de entes queridos e doenças; o retrato da vida de um povo que experimentou as múltiplas faces da modernização que tomava sua terra: avanço material mesclado com as mazelas resultantes de uma política educacional militarista e autoritária. Foi em meio a esse cenário que Meishu-Sama experienciou a diversidade cultural existente no Japão de seu tempo. À época, Tóquio era não somente palco de um intenso movimento social, mas também espiritual. Entre as várias manifestações religiosas daquele tempo, é possível destacar a crescente atividade missionária dos cristãos católicos e protestantes.

O cristianismo foi introduzido no Japão pela primeira vez em 1549, pelas mãos de missionários católicos. Entretanto, devido à proibição imposta pelo governo Tokugawa, sobreviveu na clandestinidade, tendo sido reintroduzido no país, dessa vez, por protestantes no período Meiji. Escolas e hospitais construídos por missionários e professores cristãos foram importantes meios para a absorção dos conhecimentos ocidentais por parte dos japoneses.

As atividades promovidas pelo Exército da Salvação ${ }^{5}$ também eram comuns. Há registros de que Meishu-Sama teria contribuído com donativos a essa instituição. Além do mais, ele teria sido convidado por conhecidos a se converter à religião Tenrikyo, mas se mostrou desinteressado. Chegou a procurar Ekai Kawaguchi, famoso bonzo da religião Obaku que pesquisou a religião budista no Tibete, mas também não se converteu.

\section{Entremeios: experiência na Oomoto, religiosidade budista de Kannon e visão cristã de Messias}

Foi apenas em junho de 1920 que Meishu-Sama, após frequentar palestras de divulgação da religião Oomoto na capital japonesa, tornou-se omotano. Dois teriam sido os motivos principais que o atraíram para essa religião: o ideal de reforma e reconstrução do mundo e a noção sobre a toxicidade dos remédios. Esteve afastado da Oomoto por três anos, mas continuou pesquisando o Ofudesaki - o livro sagrado dessa religião.

Foi introduzido no Japão, em 1895, com a chegada de 14 salvacionistas vindos da Inglaterra. Yamamuro Gunpei foi o primeiro salvacionista japonês e se empenhou tenazmente na criação de centros de tratamentos para tuberculosos. 
A partir de 25 de dezembro de 1926, durante três meses, Meishu-Sama teria entrado em estado de transe e recebido uma série de revelações sobre o passado e o futuro da humanidade, bem como, de sua própria pessoa, além de previsões acerca de situações mundiais do pós-guerra. Temendo represálias de correntes do controle das autoridades no tocante a questões religiosas, teria queimado todos os registros dos conteúdos dessas revelações.

Como diretor da filial da Editora Meiko, criada pela Oomoto, MeishuSama colaborou ativamente nas atividades literárias da religião. Em 1928, tornou-se divulgador da Oomoto e, em fevereiro de 1929, foi nomeado membro executivo da Sede de Tóquio. Na ocasião, manifestou diversos milagres entre fiéis que, posteriormente, se tornaram seus primeiros discípulos messiânicos. Sucessivos fatos misteriosos constituíram a base para a criação da nova religião que seria fundada mais adiante.

A Oomoto vinha sofrendo sérias repressões por parte do governo que, temendo seu rápido crescimento, reprimiu o movimento religioso em 1921 e 1935, alegando ofensas à pessoa do imperador e violação à lei de imprensa. A última e mais violenta repressão, em 1935, contou com a destruição de templos omotanos, interdição de associações, destruição de árvores e imagens sagradas, além do aprisionamento dos líderes religiosos Onisaburo e sua esposa Sumi durante mais de seis anos (PEREIRA, 1992, p. 157-158).

Embora tenha continuado ligado às atividades da religião Oomoto até 15 de setembro de 1934, Meishu-Sama já se empenhava na cura de doenças desde o início da década de (19)30. Consta que um dos motivos que o levaram a se afastar da Oomoto tenha sido o fato de que, ao invés de empenhar-se nas campanhas ideológicas da religião, ele tenha priorizado atender aos pedidos de pessoas acometidas com os mais variados tipos de doenças e outros infortúnios (FUNDAÇÃO MOKITIOKADA, 1985, p. 339).

Em dezembro de 1934, Meishu-Sama compôs uma oração - a Zenguen Sanji ${ }^{6}$-com base no sutra Kannon, ou seja, o $25^{\circ}$. sutra dos 28 sutras Hoke (Sutra de Lótus) -um dos mais importantes livros do budismo. O conteúdo dessa oração se baseia na crença de que Kannon tornou-se o Deus da Salvação do Mundo que estabelece na Terra o Paraíso, perfeito em luz e deleite. Kannon ou Messias (em linguagem cristã) é quem salva todos os seres vivos e providencia um mundo paradisíaco em que "fartas colheitas enchem os celeiros, rica é a pesca! (...) os países, sem fronteiras! O conflito e o ódio

6 Literalmente, Zenguen Sanji significa "palavras de bem e de louvor". Também pode ser traduzida como "Oração de Louvor a Deus". 
entre as pessoas e as etnias desaparecem como num sonho" (FUNDAÇÃO MOKITI OKADA, 2018, p. 62-66).

Nessa época, Meishu-Sama centralizou suas atividades na confecção de caligrafias e pinturas de Kannon, feitas em diversos tamanhos. Em vários trechos de seus diários, ele registrou sua ligação com Kannon. Por sua vez, no ano de 1935, recebeu a qualificação de sacerdote xintoísta. Segundo consta, essa qualificação teria sido uma medida cautelosa com vistas ao desenvolvimento da Obra Divina "numa época em que as autoridades eram rigorosas com as novas religiões" (FUNDAÇÃO MOKITI OKADA, 1985, p. 372).

Após alcançar o Estado de Suprema Iluminação - concedido por Deus -, Meishu-Sama reconhece sua grande missão de edificação de uma nova civilização material e espiritualmente desenvolvida.

Com a finalidade de cumprir sua missão, em 1935 ele instituiu a Associação Kannon ${ }^{7}$ do Japão e, posteriormente, em 1947, a Igreja Kannon do Japão, em meio às intensas transições que a sociedade japonesa passava após a derrota na Segunda Guerra Mundial (1939-1945). Em 1935, ele ministrou o Curso Kannon (anteriormente chamado de Curso de Terapia Japonesa), que pode ser considerado a primeira formação de novos membros do que, mais tarde, seria a religião messiânica. Seu conteúdo esclarecia, entre outros pontos, a verdadeira natureza de Kannon, a realidade dos mundos Divino, Espiritual e Material, a missão do homem, além de princípios e métodos para a obtenção da saúde, em meio aos fundamentos da Agricultura Natural.

Aqui o Johrei era conhecido como "Tratamento Espiritual de Digitopuntura Estilo Okada", e ao longo da História sofreu diversas modificações até chegar ao que é praticado na Igreja Messiânica da atualidade. Aliás, o nome da igreja também era diferente do que hoje conhecemos.

Nesse ínterim, como meio de continuar suas atividades, em maio de 1936, Meishu-Sama instituiu a Associação Japonesa de Saúde, na qual realizava sua atividade de salvação, em Tóquio. Paralelamente, seus discípulos desenvolviam atividades em outras localidades. Alguns meses depois, Meishu-Sama foi intimado a comparecer à delegacia de Omiya, no Estado de Saitama, e foi preso. Era nesse mesmo local que seu discípulo Yoshihide Takei desenvolvia atividades terapêuticas. Nessa cidade, existia uma fábrica, a Tecelagem Katakura, onde trabalhavam mais de mil operárias, algumas das quais, doentes, ficaram curadas por meio do tratamento ministrado por

Essa era a divindade que Meishu-Sama salientava como sendo a fonte da Luz do tratamento espiritual. 
Takei. A cura dessas operárias chamou a atenção das autoridades locais, sob a alegação de que tais práticas contrariavam a Lei da Medicina. Takei foi denunciado e detido pela polícia e, mais tarde, como presidente da Associação Kannon, Meishu-Sama respondeu pela culpa (FUNDAÇÃO MOKITI OKADA, 1985, p. 81-83).

É importante ter em mente que, no Japão do início do século XX, qualquer possível contrariedade ao sistema sociopolítico e econômico que vinha se constituindo em torno da modernização e industrialização do país - centrada na divinização do imperador e da militarização - era tida como uma ameaça mortal. Sobre as perseguições da época, Meishu-Sama assim se expressou:

Com um depoimento falso feito por meios forçados, acabam transformando um cidadão bom num cidadão mau. Por isso acho que este mundo é realmente terrível. Através do fato em questão, podemos ver o quanto as autoridades da época eram tiranas e feudais. A partir daquele momento, por ter entrado para a lista negra, eu vivia pressionado. Todas as vezes que mudava de residência, tinha de comunicar à polícia local, que não cessava de exercer vigilância sobre mim, fazendo tudo para me incriminar. Por isso, além de nada poder fazer, eu estava sempre preocupado e nem sequer conseguia dormir tranqüilo, por saber que a qualquer momento poderia ser preso ou ter a minha casa revistada. Dessa forma, pode-se dizer que, até o fim da Segunda Guerra Mundial, as novas religiões recebiam o mesmo tratamento que o comunismo. Em face de tal situação, eu sempre pensava: 'Embora esteja realizando ações tão benéficas para a humanidade, sou oprimido desse jeito! Que tristeza! Entretanto, isso também é um aprimoramento que Deus me dá. Pensando assim, reprimia a ira' (FUNDAÇÃO MOKITI OKADA, 1984, p. 83).

Diríamos que o período entre 1936 e 1947 foi quando Meishu-Sama e seus discípulos mais vivenciaram pressões por parte das autoridades. Nessa época, a religião não estava oficialmente estabelecida, quer dizer, existiam apenas as clínicas dos seus discípulos. Em 1950, após o término da guerra, finalmente ocorreu a instituição da Igreja Messiânica Mundial (IMM) introduzida no Brasil por imigrantes japoneses na segunda metade do século XX. Nesse cenário, fica nítida a intenção de Meishu-Sama de ampliar sua igreja ao maior número de pessoas possíveis, visto que, em 1947 falava-se em "igreja do Japão" e três anos depois, em "igreja mundial'. Inclusive, o uso da palavra "Messias" no nome da instituição, no lugar de "Kannon", revela outra intenção de Meishu-Sama - aproximar-se do Ocidente, por meio de um conceito empregado em países cuja tradição é judaico-cristã. 
(...) que Kanzeon Bossatsu, atuando para a salvação da humanidade como Buda, passara a atuar como Deus, que era a sua verdadeira natureza; que a sua função, até ali mais restrita ao Oriente, dava um grande salto, passando a ser de âmbito mundial — salvar toda a humanidade — e que a Igreja Messiânica Mundial era a manifestação de tudo isso (FUNDAÇÃO MOKITI OKADA, 1984, p. 206).

Nesse fragmento, na visão de Meishu-Sama, Kanzeon Bossatsu (Kannon) passa a atuar como Deus e não como Buda. Isso é intrinsecamente relacionado a um aspecto crucial da Teologia Messiânica: a Transição da Era da Noite para a Era do Dia. Na Era da Noite os ensinamentos búdicos, associados à Lua, predominavam; já na Era do Dia, perdem força e os ensinamentos relacionados ao Sol tomam destaque. Na Teologia Messiânica, os ensinamentos da Era do Dia são os próprios ensinamentos de MeishuSama, os quais são sobre saúde, alimentação, agricultura, arte, política, educação, entre outros assuntos, e servem como orientação para a mudança da cultura materialista em altruísta e espiritualista. Além disso, sua vida e obra se tornam a referência messiânica para a construção de um mundo ideal, o paraíso terrestre, em que a saúde, a prosperidade e a paz são plenas.

Quanto à relação entre a religião messiânica e o cristianismo demandamse estudos futuros, mas se pode dizer que, efetivamente, vêm se tornando uma urgente necessidade, sobretudo, nos últimos tempos, desde que o neto de Meishu-Sama - Yoichi Okada - tornou-se o Quarto Líder Espiritual (Yondai Kyoshu-Sama) da religião, o qual busca lançar luzes à temática de "Messias".

(...) Sempre falamos que 'nossa missão é construir um Paraíso na Terra'. Porém, como pode a Terra se tornar um Paraíso se nos esquecemos da missão de Deus? Como poderá qualquer pessoa alcançar a verdadeira felicidade sem se tornar ciente de sua verdadeira missão de se tornar um filho de Deus, um Messias? (YONDAI-SAMA, 2018).

Tendo em consideração a exegese e hermenêutica, essa é uma afirmação substancial, necessária de ser estudada e desempenhada. É também aquela que incita o que na Teologia Messiânica se denomina Kyudoshin, ${ }^{8}$ além de se relacionar à visão de Meishu-Sama sobre o ser humano depender do seu sonen ${ }^{9}$ e de ser capaz de traçar o seu destino com base na sua íntima e inseparável ligação com o Supremo Deus.

Esforço incansável na procura do caminho verdadeiro ou sabedoria verdadeira.

Sonen: palavra japonesa comumente traduzida como "pensamento", a qual não se limita ao ato de pensar racionalmente. Seu significado abrange o sentimento, a vontade e a razão. 


\section{Salvação ampla e inovadora: gênese e propósito da religião de Meishu-Sama}

Como já visto, Meishu-Sama iniciou a obra de salvação do povo por meio de uma associação instituída inicialmente com o nome de um bodhisattva conhecido por Kannon - alvo de uma fé professada no Japão por pessoas de variadas classes sociais. A figura de Kannon aparece em muitas escrituras budistas Mahayana como encarnação da salvação do mundo, recebendo nomes variados conforme sua atuação.

Meishu-Sama entronizou na sede da Associação uma grande imagem de "Kannon de Mil Braços", desenhada por ele em 1934. Poucos dias após a instituição da Associação, ele dirigiu uma palestra aos fiéis a respeito de Kannon, distinguindo seu ponto de vista sobre Kannon dos demais existentes nos sutras budistas. Em sua concepção, Kannon - alvo de fé da Associação Kannon do Japão - não se limitaria à concepção budista; seria "o Ente Absoluto, fonte de todas as divindades, Deus Salvador que deseja vivificar todos os seres" (FUNDAÇÃO MOKITI OKADA, 1984, p. 40).

Referências à relação entre Kannon e o fundador são observadas na literatura por ele próprio produzida. A "presença” de Kannon no início remoto da religião messiânica poderia indicar uma marca de ruptura ${ }^{10}$ de Meishu-Sama com sua religião anterior, a Oomoto. Todavia, tanto a experiência na Oomoto, como a descoberta de sua ligação com a divindade budista Kannon, ocorreram em meio a um contexto histórico muito particular e conturbado.

Como se sabe, a modernização do Japão se deu sob um regime autoritário e com a característica peculiar de junção do poder político e espiritual na figura do imperador. Para o governo, que tentava impor o capitalismo no país, esse regime era um instrumento ideológico e político extremamente conveniente e eficaz. Numa época em que os governantes ressuscitavam o divino imperador com uma nova roupagem, o povo, por uma rota independente, foi levando seu próprio deus ao palco da História. Nasceram assim as novas religiões japonesas (NRJ) e seus respectivos fundadores, os verdadeiros deuses vivos.

A sigla NJR designa os novos movimentos religiosos surgidos no Japão a partir do século XIX e, sobretudo, no século XX. Embora as bases doutrinárias das NRJ não sejam de fato novas, pois trazem consigo traços inerentes a religiões tradicionais, a forma de organização e combinação desses

10 Conjecturas a partir da leitura de ARAKI (vol. 22, 1996 p. 16-17), que propõe o debate sobre as (des)continuidades da religião messiânica com a Oomoto. 
aspectos doutrinários pode ser considerada inovadora. Inovação e potencial de expansão fora do Japão são características comuns a várias NRJ.

A ideia de que os fundadores das NRJ constituem veículos para a inovação cultural ou revitalização de parte do sistema sociocultural japonês é tratada com propriedade e riqueza de detalhes por Pereira (1992), em especial, no caso de Miki Nakayama e Nao Deguchi, ambas fundadoras de NRJ, respectivamente, Tenrikyo e Oomoto. Segundo o autor, assim como foram inovadoras ou reinventoras de uma nova cultura, Miki e Nao, por sua vez, "perpetuaram igualmente a tradição em alguns aspectos" (1992, p. 138). Inicialmente, eram "profissionais xamânicos independentes" e, com o crescimento do número de adeptos, passaram a ser consideradas ikigami ou deusas vivas, tendo por fim se tornado kyoso ou fundadoras de religiões (1992, p. 110-111).

Em 30 de setembro de 1953, Meishu-Sama escreveu sobre a pressão sofrida na fase inicial da religião no Japão e as medidas de adaptação das quais se utilizou até a fundação da Igreja Messiânica Mundial, como instituição religiosa no pós-guerra:

Só em agosto de 1947 a nossa Igreja Messiânica Mundial foi fundada como entidade religiosa e começou a desenvolver suas atividades abertamente. Até então, a pressão por parte das autoridades era intensa, e por isso, como é do conhecimento de todos, ela vinha desenvolvendo a terapia popular sob a denominação 'terapia de purificação japonesa'. Todavia, entre as pessoas que não tinham fé, a cura das doenças não era absoluta, e por esse motivo, dependendo da pessoa, eu fazia com que ela orasse diante da imagem de Kannon pintada por mim. Tal procedimento era aceito pelas autoridades, que, desde antigamente, diziam não ser problema esse tipo de fé. A esse ponto as autoridades detestavam as religiões novas... Felizmente, o mundo tornou-se democrático e foi permitida a liberdade em matéria de Religião. Desde então, pudemos desenvolver livremente as nossas atividades como organização religiosa. $\mathrm{Na}$ época, as pessoas que poderiam ser consideradas como membros eram apenas de duzentas a trezentas (FUNDAÇÃO MOKITI OKADA, 2000, p. 135).

Após o término da Segunda Guerra Mundial, a realidade da IMM alterou-se completamente não somente no Japão, como no exterior. Conforme Meishu-Sama descreve, na continuação do excerto anterior, a religião messiânica experimentou vertiginosa expansão: 
Como todos estão cientes, em agosto deste ano a Igreja estará completando seis anos de existência, e é surpreendente o número atual de membros, que somam algumas dezenas de milhares. Existem 3.242 ministros; igrejas grandes, 4 unidades; igrejas médias, 88 unidades, e 524 filiais. A Igreja vem se expandindo dessa maneira e promete crescer ainda mais vigorosamente, a cada dia e a cada mês. Além disso, a partir da primavera deste ano, ela será ampliada no Havaí e, no verão, nos Estados Unidos. No que se refere à expansão, o número dos membros do Havaí, num período de mais ou menos meio ano, já ultrapassou a casa dos mil. Recentemente, foi adquirido, por 50 mil dólares, um terreno com casa, que poderá se tornar uma magnífica Sede Central; ao mesmo tempo, entre os membros nativos, pessoas fervorosas têm se tornado dirigentes das unidades filiais, que já são inúmeras. Atualmente, estão sendo criadas outras unidades em várias localidades. Nos Estados Unidos, também, no mês de agosto será inaugurada uma filial, e dias atrás recebi um relatório dizendo que o número de participantes nos cursos de iniciação tem aumentado dia a dia, tudo indicando que, no futuro, vai ser incalculável a expansão da Igreja naquele país (FUNDAÇÃO MOKITI OKADA, 2000, p. 135).

Entre 1935 e 1947, em um curto período de 12 anos, Meishu-Sama passou de um simples religioso a um messias seguido por milhares de pessoas. Sua ação messiânica se expandiu por todo o Japão em pouco tempo e, a partir da década de (19)50, ele passou a liderar pessoalmente a construção de edificações, jardins e museus que constituiriam os Solos Sagrados que representam o paraíso terrestre. A partir de então, ele também se dedicou à escrita de Ensinamentos ou Escritos Divinos - que posteriormente viriam a constituir a base da doutrina messiânica.

Entre os textos em que Meishu-Sama aborda o tema das NRJ, têm-se: "Religião antiga e religião moderna"; "O que é uma religião nova"; "Religiões novas e religiões tradicionais"; "Religião e seitas" - publicados na coletânea Alicerce do Paraíso, ${ }^{11}$ editada em português em cinco volumes. Além disso, em geral, ao explanar sobre paraíso terrestre que é o propósito final da religião messiânica, ele critica a fé das pessoas que buscam apenas a salvação espiritual, desprezando a salvação material, vivenciada neste mundo.

É condenável salientar os defeitos alheios, mas, neste momento, devo fazer referência às pessoas que, embora possuam fé, tombam nas garras de doenças fatais ou continuam vivendo de forma miserável, porém satisfeitas e contentes. Comparando-as com os descrentes, pode ser que estejam salvas

11 Compilação de Ensinamentos de Meishu-Sama. 
espiritualmente, mas não fisicamente. A salvação foi feita pela metade. A Verdadeira Salvação abrange o espírito e o corpo. Numa família, todos devem tornar-se saudáveis, libertar-se da pobreza e usufruir de alegria plena. Até hoje, porém, visava-se apenas à salvação do espírito, não havendo preocupação com o corpo físico; todos se resignavam, considerando que a Fé limita-se à salvação da alma. Muitos religiosos afirmam que a Fé que busca obter graças imediatas é de nível inferior. Trata-se de uma concepção lógica, pois não há quem não aspire a graças imediatas. Se alguém se queixa de dores físicas, é estranho retrucar que o homem deve superar a vida e a morte. Ora, ninguém é capaz de tal superação. Pensar que se conseguiu tal coisa é enganar a si próprio (MEISHU-SAMA, 2005, p. 45).

O tema visto no fragmento citado se relaciona a um aspecto da mensagem messiânica de Meishu-Sama conhecido em japonês por gento riyaku (現「利蓝), isto é, as graças recebidas na vida presente que estão intimamente ligadas à salvação por meio da prática da fé que deve ser vivida no dia a dia (shinko seikatsu 信仰即生活).

Por sua vez, Meishu-Sama escreveu vários artigos em que fala de si, da sua missão e ainda da sua própria experiência mística de relação com o divino. Em particular, no texto "Sou Deus ou ser humano?”, ele diz o seguinte:

Naturalmente, sou religioso, mas não sou um fundador de religião como o foram Sakyamuni ou Jesus Cristo; tampouco sou um personagem sobrenatural. Em verdade, abranjo aspectos muito amplos. (...) Conseqüentemente, no futuro, quando se fizerem pesquisas sobre minha pessoa, inevitavelmente surgirão inúmeras críticas. Com este pensamento, quero deixar retratada a minha imagem mais real (FUNDAÇÃO MOKITI OKADA, 1985, p. 36).

Nesse mesmo texto, ele expressa sobre a mística que envolve a nova religião que Deus lhe confiou a fundar:

O mistério dos mistérios é a fé (...). Em comparação, algumas novas religiões encerram muitos mistérios e por isso, embora criticadas, passaram à frente das religiões tradicionais e estão se expandindo amplamente. (...) Modéstia à parte, não existe religião tão cheia de mistérios quanto a nossa Igreja Messiânica Mundial (FUNDAÇÃO MOKITI OKADA, 1985, p. 35).

É nesse contexto de experiência de Deus - dessa mística vivida por Meishu-Sama no aqui e agora da História - que a percepção da unidade com Deus por meio do nome messias pode ser ampliada e vivida por todos aqueles 
que se identificam com os ideais messiânicos de um mundo de Verdade, Bem e Belo - o Paraíso, mundo de luz em que reinam a paz, alegria e felicidade. Afinal, a mística é:

...experimentar Deus em todo o ser e senti-lo no coração. Dialogar com ele, chorar diante dele, alegrar-se nele, confiar a Ele a vida e o destino e mergulhar em seu mistério. (...) Então, todos os lugares da pessoa são tomados por Deus; o corpo, a alma e o espírito. Pode-se chegar a um ponto em que a pessoa se sente unida e fundida com Deus como testemunha São João da Cruz, um dos maiores místicos cristãos (...). Então, não se precisa crer em Deus. Sabese de sua existência. Estamos tão ligados a Ele que nossa vida não pode ser mais pensada e vivida sem uma referência emocional e amorosa com Deus (BETTO, 2010, p. 40).

\section{Considerações finais}

Em consonância com a espiritualidade messiânica, com relação à experiência de Deus, é importante destacar que esta não ocorre no mundo celestial, nem em alguma experiência extra-humana. Se assim fosse, não seria uma experiência humana e, portanto, não transformaria a realidade em que vivemos. Semelhantemente ao que afirmou Sung quanto à espiritualidade cristã:

Enganam-se aqueles que pensam que devemos negar a nossa humanidade e 'fugir do mundo' para encontrar Deus. Fora da nossa condição humana não podemos conhecer e nem experimentar nada. (...) Se é que podemos dizer assim, a parte humano/cotidiana e a parte divina não podem ser separadas. Ou existem experiências humanas que são portadoras da experiência de Deus ou nós não podemos conhecer a Deus. Sendo assim, nossa busca de experienciar Deus deve se dirigir às experiências da nossa vida comum, cotidianas, históricas (2008, p. 45-46).

Meishu-Sama experimentou o estado de unidade com Deus - a qualidade de ente celestial, ou messias. Ele estendeu essa boa-nova a qualquer pessoa, independentemente de credo, raça ou qualquer diferenciação. Convidou qualquer pessoa a se identificar com o seu objetivo, afirmando:

...uma vez se tornando membro da Igreja Messiânica Mundial, qualquer pessoa consegue manifestar um poder semelhante ao do fundador de uma religião. Um simples fiel manifestar milagres é coisa mais do que comum em nossa Igreja; é, realmente, uma extraordinária graça material. Além disso, através dos nossos ensinamentos, esse fiel consegue captar a essência da vida, despertar para a Verdade, melhorar sua vida cotidiana e ficar mais alegre; sustentado por inabalável fé, pode até mesmo vislumbrar o futuro. Assim, ele passa a viver com verdadeira segurança e tranqüilidade. A prova mais evidente é que, 
com o decorrer do tempo, suas feições e sua pele melhoram. Isso acontece porque, uma vez que seu sangue se torna mais puro, sua saúde aumenta, desaparecem suas incertezas quanto ao futuro, seu caráter se eleva, e ele se torna uma pessoa virtuosa. Dessa forma, ganha maior confiança de terceiros e por eles é respeitado (FUNDAÇÃO MOKITI OKADA, 1985, p. 54-55).

Para Meishu-Sama, o povo pode e deve ser o senhor do seu destino. O primeiro passo é se decidir pelo Caminho da Luz, identificando-se e agindo em conjunto com Deus na execução do seu plano de trabalho para a construção do mundo livre de doença, pobreza e conflito nesta vida. Foi assim que ele viveu e deixou uma mensagem messiânica que inspira milhares de seguidores em vários cantos do mundo, mesmo após a sua morte em 1955.

\section{Referências}

ARAKI, Michio. In: Okada Mokichi Zenshu Tyojyutu-hen furoku, v. 13 e 22. Okada Mokichi Kenkyu. Japan: 1995 e 1997 [Obras Completas de Mokiti Okada. Volume Escritos - Anexos da Pesquisa Mokiti Okada v. 13 e 22].

BETTO, Frei; BOFF, Leonardo. Mística e Espiritualidade. Petrópolis, Rio de Janeiro: Vozes, 2010.

FUNDAÇÃO MOKITI OKADA (org.). Luz do Oriente, v. 3, 1. ed., 1983.

Luz do Oriente, v. 2, 2. ed., 1984.

. Luz do Oriente, v. 1, 3. ed. São Paulo, 1985.

. "Principal causa da expansão da nossa Igreja." In: O Pão Nosso de cada Dia: o

Alimento Espiritual do Cotidiano. São Paulo: FMO, 2000.

Orações: Salmos e Hinos, 2. ed. São Paulo, 2018.

MEISHU-SAMA. "Paraíso Terrestre." In: Ensinamentos de Meishu-Sama - Coletânea Alicerce do Paraíso, v. 5, 8. ed. São Paulo: FMO, 2005.

" "Verdade, Bem e Belo." In: Ensinamentos de Meishu-Sama - Coletânea Alicerce do Paraíso, v. 1, 6. ed. revisada e ampliada. São Paulo: FMO, 2017.

PEREIRA, Ronan Alves. Possessão por espírito e inovação cultural: a experiência religiosa das japonesas Miki Nakayama e Nao Deguchi. São Paulo: Aliança Cultural Brasil -Japão / Massao Ohno Editor, 1992.

SUNG, Jung Mo. Se Deus existe, por que há pobreza? São Paulo: Editora Reflexão, 2008. YONDAI-SAMA. Mensagem de Ano Novo de Kyoshu-Sama em $1^{\circ}$. de janeiro de 2018. Disponível em: <http://www.messianica.org.br/meishu-sama/kyoshu-sama/mensagem-deano-novo-2018>. Acesso em: 7 set. 2018.

Submetido em: 22-11-2018

Aceito em: 25-11-2018 